\title{
Enhancement of Crude Oil Polluted Soil by Applying Single and Combined Cow-Dung and Hydrogen Peroxide as Remediating Agents
}

\section{*11BENSON, DM; OCHEKWU, EB; TANEE, FB.G}

\author{
Department of Plant Science and Biotechnology \\ Faculty of Science University of Port Harcourt, Nigeria \\ *Correspondence authorEmail: diseph4real@yahoo.com;
}

\begin{abstract}
The study aimed at enhancing the remediationof crude oil polluted soil of the Niger Delta using cow dung and hydrogen peroxide in either single or combined forms. $5 \mathrm{~kg}$ of soil each was polluted with $200 \mathrm{ml}$ of crude oil representing $4 \% \mathrm{w} / \mathrm{v}$. Five amendment treatments labelledA- E were done in order of A (polluted soil $+1.2 \mathrm{~kg}$ cow dung), $\mathrm{B}$ (polluted soil $+1000 \mathrm{ml}$ Hydrogen peroxide), $\mathrm{C}$ (polluted soil $+0.6 \mathrm{~kg}$ cow dung $+500 \mathrm{ml}$ hydrogen peroxide), $\mathrm{D}$ (polluted soil without amendment) and $\mathrm{E}$ (unpolluted soil without amendment).pH, conductivity, organic carbon, organic matter, phosphate, nitrate, total hydrocarbon content, potassium and microbial population were analyzed before and after remediation. The results showed that addition of cowdung and $\mathrm{H}_{2} \mathrm{O}_{2}$ enhanced remediation of the polluted soilespecially in treatment $\mathrm{A}$ and $\mathrm{C}$ with significant increase $(\mathrm{p}=0.05)$ in soil conductivity, $\mathrm{pH}$ and nutrients when compared to the un-amended soil. Reduction in the total hydrocarbon content (THC) was in the order of A $(79.48 \%)>\mathrm{C}$ $(77.95 \%)>\mathrm{B}(75.75 \%)>\mathrm{D}(46 \%)$ with significant increase in hydrocarbon degrading microbes in the amended soil.The amendments have the capacities to enhance remediation of crude oil polluted soil.Also, the combined treatments did not have any advantage over the single treatment options as the use of cowdung single treatment perform best in terms of its remediation potential. Therefore, nutrient enhancement should be considered a critical factor in the remediation of crude oil polluted soil. @ JASEM
\end{abstract}

\section{http://dx.doi.org/10.4314/jasem.v20i4.30}

Keywords: remediation, physiochemical, parameters, soil, crude oil.

Various activities of the oil industries ranging from exploration, exploitation, transportation, distribution and usage have been reported to affect the environment (Anyanwu et al., 2014). These activities can cause environmental damages (land, air and water pollutions). This is because they are capable of causing immediate physical, chemical and biological damage to the affected ecosystem. These problems arise mainly from the processing and distribution of crude and refined petroleum products in the oil producing areas and to areas needed (Ayotamuno et al., 2006).Petroleum hydrocarbon products affects the fertility status of the soil as most nutrients needed by plants for normal functioning have been reported to be deficient in soil polluted by crude oil (Abii and Nwosu, 2009). Significantly reduction in nitrogen and organic carbon contents of soil has been reported by Agbogidi et al., (2007); Wyszkowski and Ziolkowska, (2008).Crude oil reduces water infiltration into the soil (Michael and Ojha, 2006). This means that crude oil has water repellents property; thereby making the soil to be waterdeficient.This may have direct or indirect effects on plant, animal and microbial populations. Crude oil polluted soils may sometimes remain unsuitable for growth of plants for months or years depending on the level of contamination because its toxicity may persist for a long time.
Due to the harmful and persistence effect of pollutants such as crude oil in soil; there is need to apply remedial measures to retain the usefulness of the soil. Application of biostimulation agents that are cheap, available and environmentally friendly will help in this direction. Such materials must be capable of improving the nutrient status or increase the aeration of the soil. This is because nutrient and oxygen depletion have been observed to be major characteristics of crude oil polluted soil (Okoh, 2006). Use of animal manure has been proven to enhance the nutrient status of soil for oil degradation by natural microbial population (Boopathy, 2001; Bidwell et al., 2002) Animal manure such as cow dung has been found to improve soil physical and chemical conditions as well as maintaining an adequate supply of soil organic matter (Powel et al., 1998; Ikpe and Powel, 2002). Hydrogen Peroxide is a chemical liquid that is capable of increasing dissolved oxygen content in the soil or groundwater which could enhances crude oil biodegradation. In the Niger Delta areas of Nigeria, petroleum hydrocarbon spills are common and inevitable hence the impact of this menace will continue; there is need to apply some secondary treatment measures. The use of animal dung and other bio-stimulants have been studied but little work has been done on the combination of these treatments on remediation of crude oil polluted soil. Hence, the objective of this work is to ascertain the advantage of combined 
treatment over the single treatment of cow dung and hydrogen peroxide $\left(\mathrm{H}_{2} \mathrm{O}_{2}\right)$ in the remediation of crude oil polluted soil.

\section{MATERIALS AND METHODS}

Description of experimental Site:The study was conducted out at the Centre for Ecological Studies, University of Port Harcourt, Port Harcourt, Nigeria at Latitude $4^{0} 00 \mathrm{Nand} 5^{\circ} 00 \mathrm{~N}$ and Longitude $6^{\circ} \mathrm{E}$ and $7^{0}$ E.A fallow land located close to the Faculty of Agriculture Demonstration farm was used for soil collection.

Soil collection and pollution: Soil were collected from this area, homogenized and bulked; then taken to the Ecological Centre (the experimental site). A total of 40 buckets was used for the experiment with each bucket filled with $5 \mathrm{~kg}$ of the soil. Crude oil obtained from Nigerian National Petroleum Corporation (NNPC), Eleme, Port-Harcourt was applied as the pollution treatment. $200 \mathrm{ml}$ of the crude oil was added to the soil in each bucket representing $4 \% \mathrm{v} / \mathrm{w}$ pollution level alongside a control of $0 \% \mathrm{v} / \mathrm{w}$ (untreated soil). The soil and oil were thoroughly mixed inside the bucket and allow to settling for 2 weeks under natural environmental conditionsbefore application of amendments. Wateringeach treatment with $0.5 \mathrm{~L}$ of water was done when it was observed that the soil was dry.

Addition of remediation agents:3\% concentration hydrogen peroxide $\left(\mathrm{H}_{2} \mathrm{O}_{2}\right)$ and cow dung obtained from an abattoir near Choba Market were used as the amendment materials. Each of these amendment materials was carefully measured and applied into the different buckets containing polluted soil with exceptions to the controls(soil with pollution but no remediation). The amendments were applied either in single or combined form as shown below:

Amendment treatment A: Polluted soil amended with $1.2 \mathrm{~kg}$ cow dung

Amendment treatment B: Polluted soil amended with $1000 \mathrm{ml}$ hydrogen peroxide

Amendment treatment $\mathbf{C}$ : Polluted soil amended with a combination of $0.6 \mathrm{~kg}$ cow dung $+500 \mathrm{ml}$ hydrogen peroxide (combined amendment)

Amendment treatment D: Polluted soil without any amendment (control)

Amendment treatment E: Soil with no pollution and no amendment (double control)the remediation treatments were properly mixed with the soil in each bucket and allowed to stand for two months. Soil analysis was done for all the treatments after application of crude oil pollution treatment (before amendment) and at the expiration of the experiment (3 month after amendment).

Soil sample analysis:Soil samples were collected for the analysis of the soil physic-chemical parameters ( $\mathrm{pH}$, conductivity, organic carbon, organic matter, phosphate, nitrate, total hydrocarbon content. and potassium).

Soil $\mathrm{pH}$ was obtained using a $\mathrm{pH}$ meter (model EQ610 EquipTronic $\mathrm{pH}$ meter). The soil electrical conductivity was determined using a JENWAY Model 4010 conductivity meter. Soil Nitrate $\left(\mathrm{NO}_{3}{ }^{-}\right)$ was determined using Brucine method (USEPA, 1971) and phosphate content was by oxidation method (Stewarte et al., 1974). Soil total organic matter (TOM) was determined by sulphuric acid $\left(\mathrm{H}_{2} \mathrm{SO}_{4}\right)$ and aqueous potassium dichromate $\left(\mathrm{K}_{2}\right.$ $\left.\mathrm{Cr}_{2} \mathrm{O}_{7}\right)$ mixture. $\%$ Organic matter $=\%$ Organic carbon x 1.724 as outlined by Osuji and Adesiyan (2005). Hence \% Organic carbon can also be gotten from total organic matter $(\%)$ as shown from the formula below:

$\mathrm{TOC} \%=\frac{T O M}{1.724}$

The soil potassium was determined by Digestion Method. The International Institute of Tropical Agriculture (IITA)(1979) mixed acid digestion method was adopted. Total Hydrocarbon Content (THC) was analyzed using a thermo-spectrum spectrophotometer and chloroform at a wavelength of $420 \mathrm{~nm}$.

Soil microbial analyses such as Hydrocarbon utilizing Bacteria (HUB) and Hydrocarbon Utilizing Fungi (HUF) were analyzed by inoculation of soil samples in Mineral salt Agar (MSA), and Total Heterotrophic Bacteria (THB) was analyzed by inoculation of soil samples in Nutrient Agar (NA), while Total Heterotrophic Fungi (THF) was analyzed by inoculation of soil samples in Potato Dextrose agar (PDA).

Statistical evaluation:The data collected were subjected to Analysis of Variance (ANOVA) using 5 $\%$ level of probability. The means of the data were separated using the Least Significant Difference (LSD). (SPSS, 2014 version)

\section{RESULTS AND DISCUSSION}

The total hydrocarbon content (THC) of the soil from the different treatments is as presented in Fig. 1. There was significant decrease in the THC content of the soil in all the treatments after the amendment 
addition as compared to the initial results obtained before amendment. The highest loss was seen in A (polluted soil amended with only cow dung) followed by $\mathrm{C}$ (polluted soil amended with combination of cow dung and hydrogen peroxide) with percentage reduction of $79.48 \%$ and $77.95 \%$ respectively. The least reduction was seen in treatment D (polluted soil without amendment).

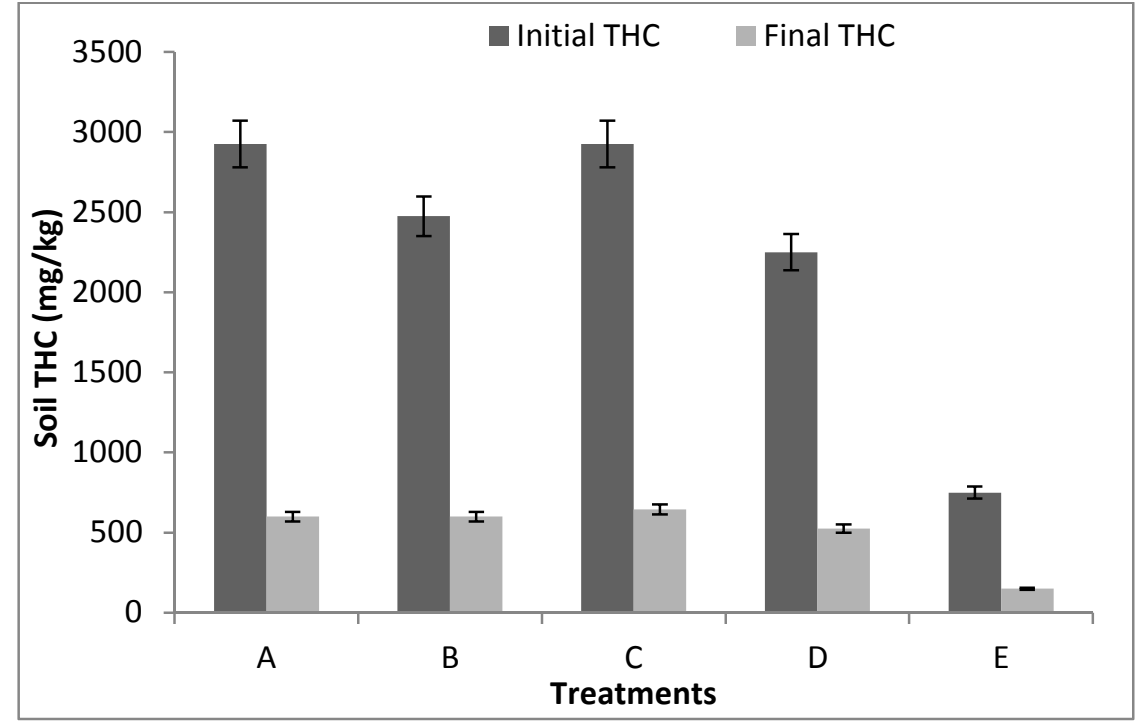

Fig 1 : Effects of Treatments on Soil Total Hydrocarbon Content (THC)

The soil $\mathrm{pH}$ for all the treatments at the beginning of the experiment was acidic. There was increase in the soil $\mathrm{pH}$ in all the treatments at the end of the experiment. The $\mathrm{pH}$ for treatments A (polluted soil amended with only cow dung) and C(polluted soil amended with cow dung and hydrogen peroxide) became alkaline while the other treatments remain at the acidic (weak) level (Fig. 2).

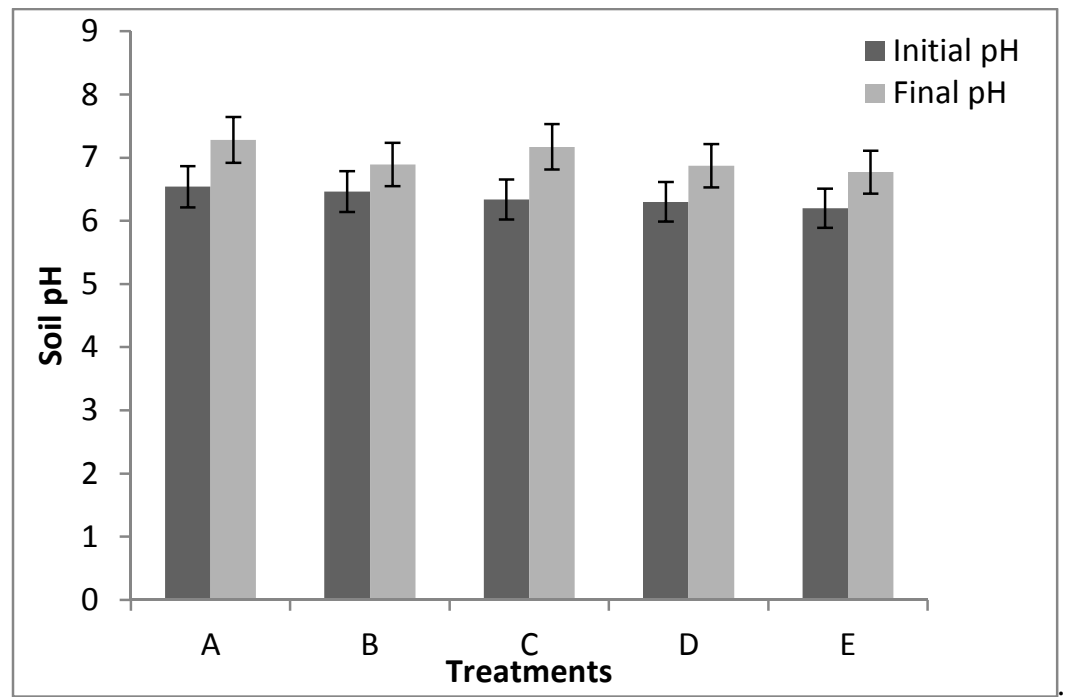

Fig. 2:Effects of Treatments on Soil pH

Fig. 3 showed that addition of cow dung as amendment material significantly $(\mathrm{p}=0.05)$ increase the electrical conductivity of the soil as were observed in treatments A (polluted soil amended with only cow dung) and C (polluted soil amended with cow dung and hydrogen peroxide combination) from initial to final. No significant difference in electrical conductivity was observed in the other treatments (B, D and E). 


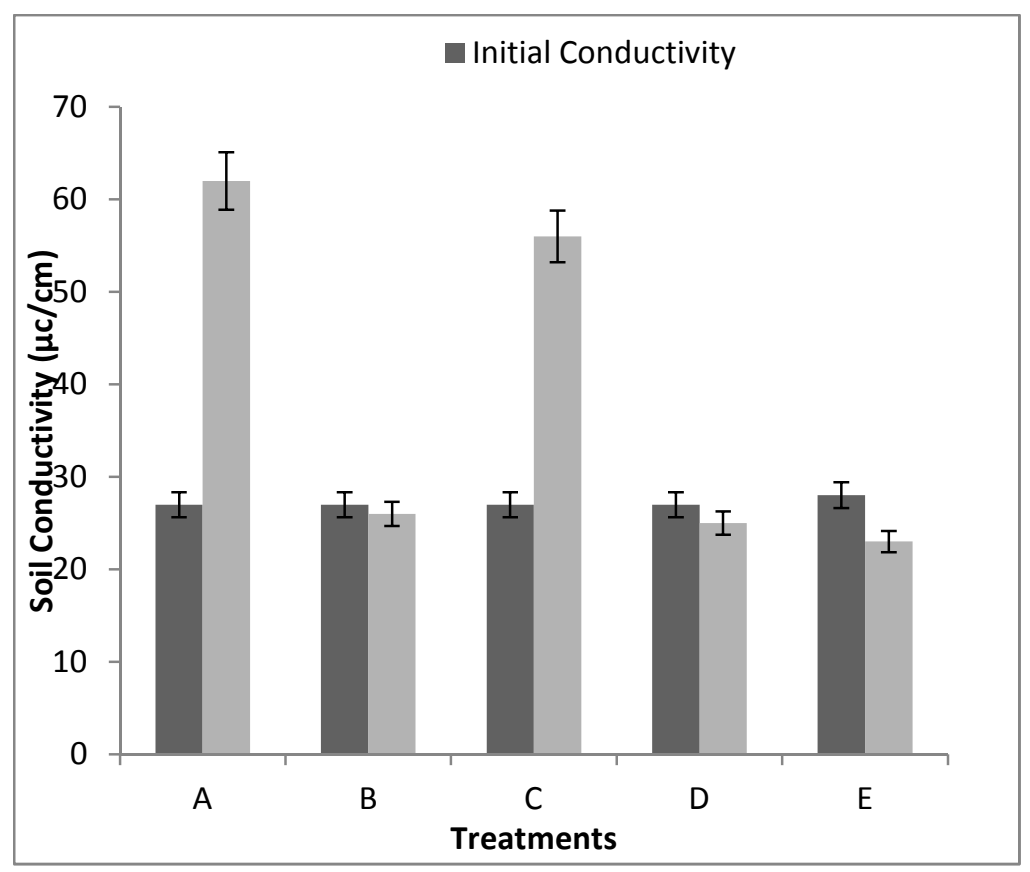

Fig. 3: Effects of Treatments on Soil Conductivity

The result for the total organic matter (TOM) is shown in Fig. 4. The TOM was significantly lower in all the amended treatments (final) when compared to treatment before amendment (initial) except in treatment D (pollution without amendment) in which the reverse was the case. At the expiration of the experiment, increase in TOM was seen in treatment $\mathrm{A}$ (polluted soil + cow dung) and treatment $\mathrm{C}$ (polluted soil + cow dung + hydrogen peroxide) among the amendment treatments. The least was seen in treatment 5 (unpolluted soil).

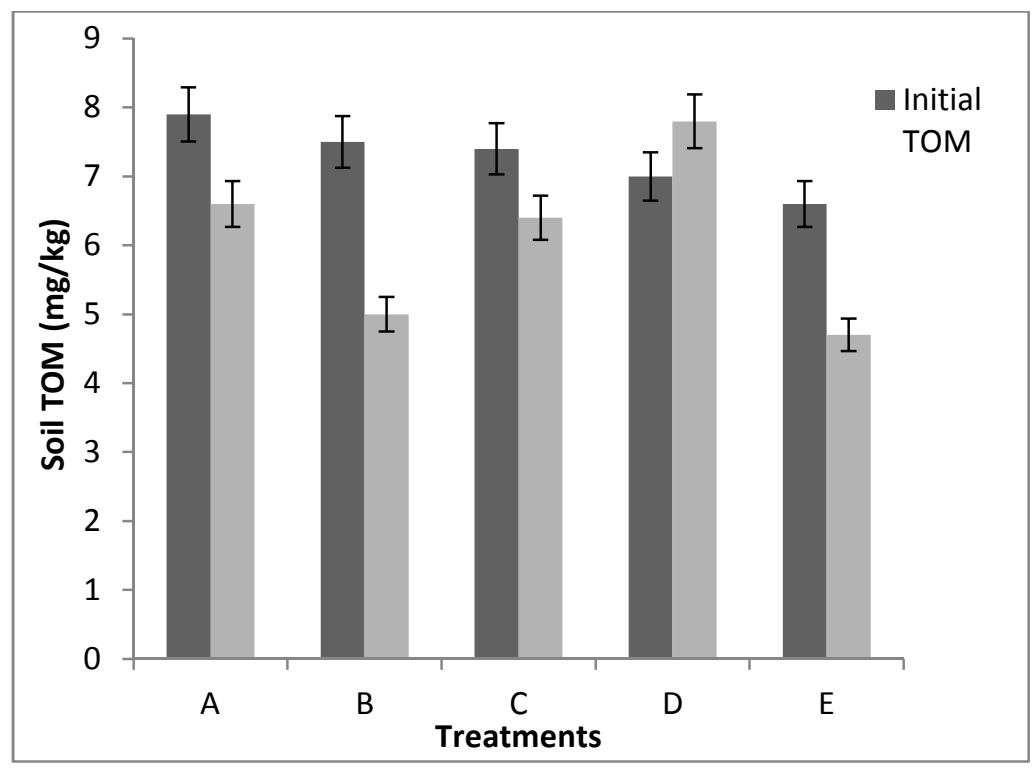

Fig. 4. Effects of Treatments on Soil Total Organic Matter (TOM)

The highest TOC value was seen in treatment A (polluted soil + cow dung) followed by treatment B (polluted soil + hydrogen peroxide), while the least was seen in treatment $\mathrm{E}$ (unpolluted soil). At the end of the experiment, the TOC for all the treatments were reduced with no significant difference between them(Fig 5). 


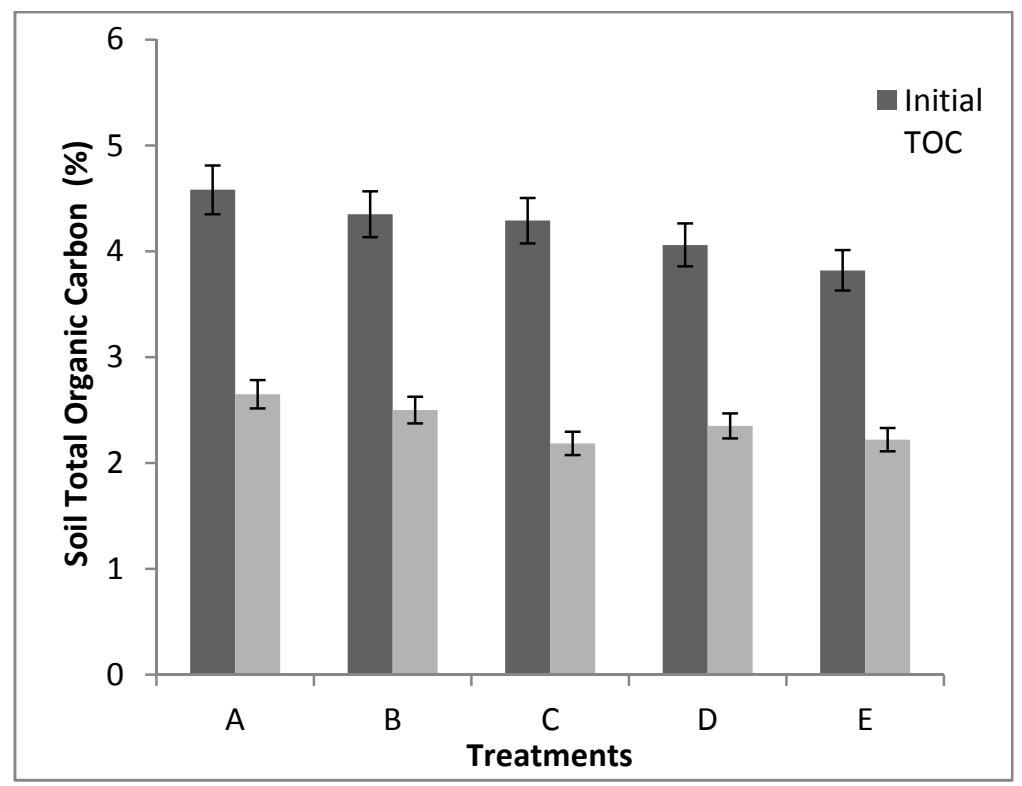

Fig. 5.Effects of Treatments on Soil Total Organic Carbon (TOC)

The results showed that the total nitrate content for treatments A ( polluted soil + cow dung only); B (polluted soil + hydrogen peroxide only), and C ( polluted soil + cow dung and hydrogen peroxide) decreased as compared to the initial while the total nitrate content of soils in treatment $\mathrm{E}$ (unpolluted soil) and treatment D (polluted soil without amendment) increased at the end of the experiment as compared to the initial(Fig 6).

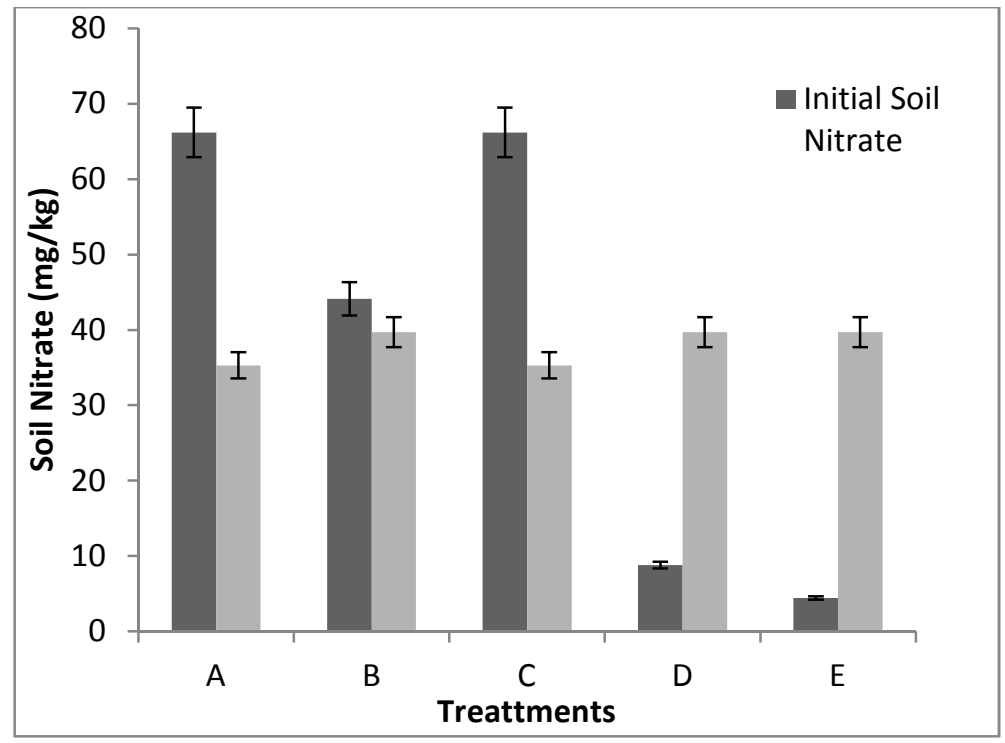

Fig. 6. Effects of Treatments on Soil Nitrate

The result showed that there was no significant improvement in the phosphate content of all the amendment treatments as the phosphate content before amendment was significantly higher than after amendment. (Fig. 7). Although at the end of the experiment, there was increase in the phosphate content $\left(\mathrm{PO}_{4}{ }^{-}\right)$in polluted soil amended with only cow dung (treatment A) and polluted soil amended with cow dung and hydrogen peroxide combination (treatment $\mathrm{C}$ ) compare to other amendment treatment options. The difference was significant at $\mathrm{p}=$ 0.05 . 


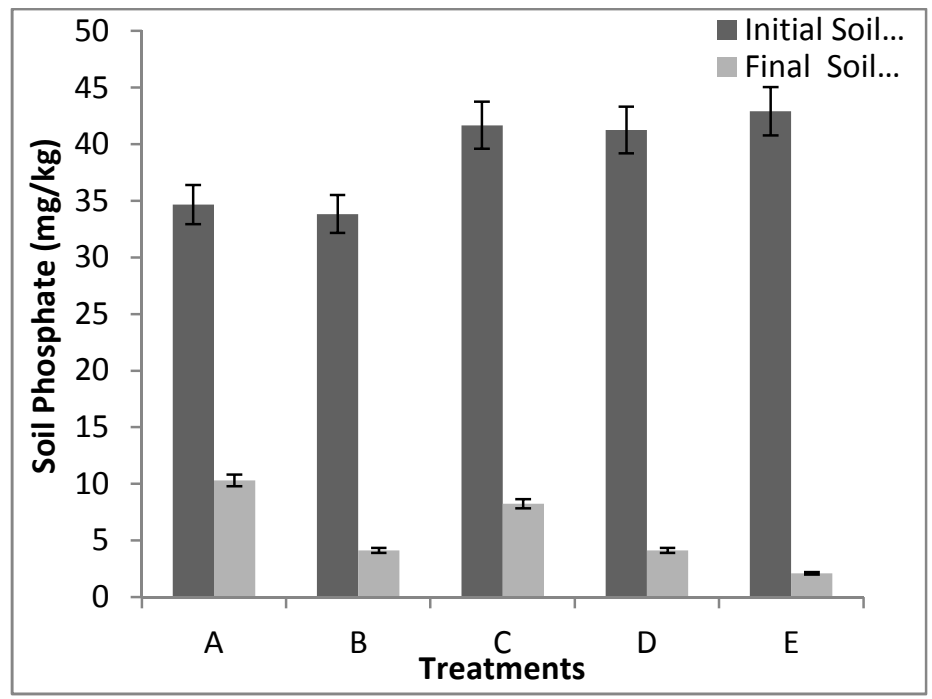

Fig. 7. Effects of Treatments on the Soil Phosphate

Similar result pattern in phosphate content was also observed in potassium content in which there was drastic reduction in the potassium content at the termination of the experiment in all the amendment treatments when compare to the potassium content before amendment. Significant improvement in potassium content at the termination of the experiment was recorded in polluted soil amended with only cow dung (treatment A) and polluted soil amended with combination of cow dung and hydrogen peroxide (treatment $\mathrm{C}$ ) as compare to other amendment treatment options as shown in Fig. 8.

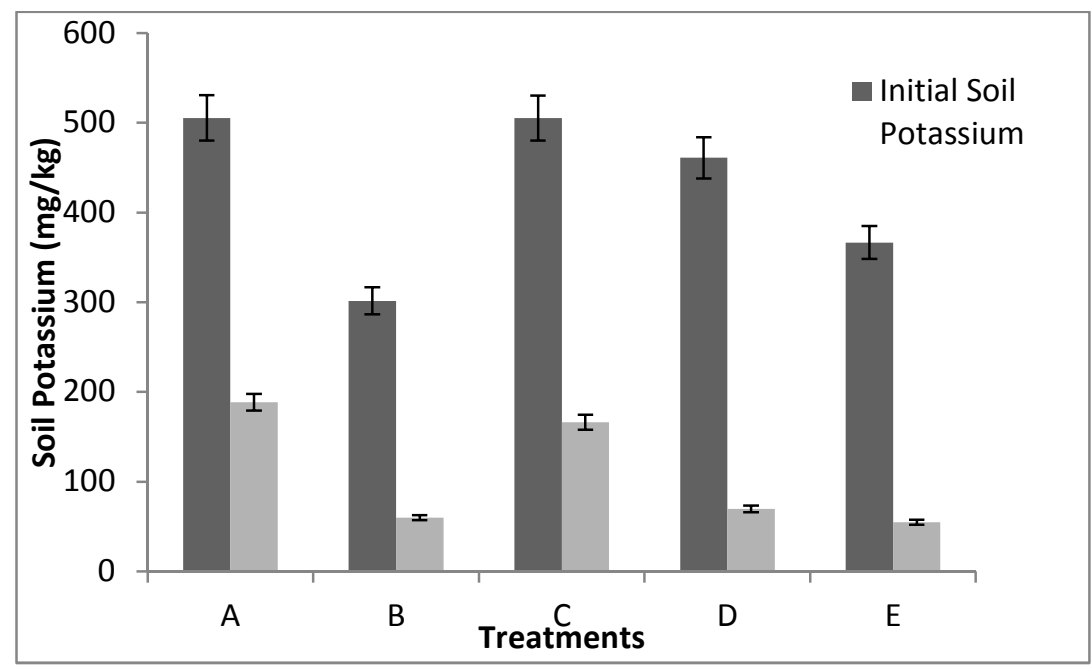

Fig. 8. Effects of Treatments on the Soil Potassium

Microbial analysis of the different amended treatments alongside the polluted but no amendment and no pollution with no amendment is as shown in Table 1. Result showed increase in the microbial population types such Total heterotrophic bacteria (THB), Hydrocarbon utilizing Bacteria (HUB), Hydrocarbon Utilizing Fungi (HUF) and Total Heterotrophic Fungi (THF) from the initial (before amendment) to the final (that is 8 weeks after amendment). At the expiration of the experiment, amendment treatment $\mathrm{C}$ (polluted soil amended with combination of cow dung and $\mathrm{H}_{2} \mathrm{O}_{2}$ ) recorded the highest THB and THF. Treatment A (polluted soil amended with only cow dung) recorded the highest HUB while treatment D (pollution with no amendment) recorded the highest HUF. 
Table 1; Effect of amendment treatments on microbial populations.

\begin{tabular}{|c|c|c|c|c|c|c|c|c|}
\hline & \multicolumn{8}{|c|}{ Microbial Types } \\
\hline \multirow{2}{*}{ Treatment } & \multicolumn{2}{|c|}{ THB (cfu/g) } & \multicolumn{2}{|c|}{ HUB (cfu/g) } & \multicolumn{2}{|c|}{ THF (cfu/g) } & \multicolumn{2}{|c|}{ HUF (cfu/g) } \\
\hline & Initial & Final & Initial & Final & Initial & Final & Initial & Final \\
\hline $\mathbf{A}$ & $5.7 \times 10^{8}$ & $26.3 \times 10^{8}$ & $2.0 \times 10^{4}$ & $7.0 \times 10^{4}$ & $1.0 \times 10^{4}$ & $2.0 \times 10^{4}$ & $1.8 \times 10^{3}$ & $2.7 \times 10^{4}$ \\
\hline B & $5.7 \times 10^{7}$ & $26.0 \times 10^{8}$ & $1.0 \times 10^{4}$ & $5.1 \times 10^{4}$ & $1.3 \times 10^{3}$ & $1.8 \times 10^{4}$ & $3.0 \times 10^{3}$ & $3.5 \times 10^{4}$ \\
\hline $\mathrm{C}$ & $12.3 \times 10^{8}$ & $28.3 \times 10^{8}$ & $1.1 \times 10^{3}$ & $1.9 \times 10^{4}$ & $1.2 \times 10^{4}$ & $5.4 \times 10^{4}$ & $1.5 \times 10^{3}$ & $3.3 \times 10^{4}$ \\
\hline D & $5.2 \times 10^{6}$ & $25.0 \times 10^{8}$ & $1.5 \times 10^{3}$ & $3.2 \times 10^{4}$ & $2.5 \times 10^{4}$ & $4.6 \times 10^{4}$ & $1.4 \times 10^{3}$ & $4.0 \times 10^{4}$ \\
\hline $\mathbf{E}$ & $4.0 \times 10^{6}$ & $24.7 \times 10^{8}$ & $1.0 \times 10^{3}$ & $2.8 \times 10^{4}$ & $1.0 \times 10^{3}$ & $1.9 \times 10^{4}$ & $1.7 \times 10^{3}$ & $3.0 \times 10^{4}$ \\
\hline
\end{tabular}

Total Hydrocarbon content is an index to determining the level and toxicity of crude oil in soil. That is the toxicity of crude oil is directly proportional to the total hydrocarbon content of the polluted site. Result showed that amended materials (cow dung and $\mathrm{H}_{2} \mathrm{O}_{2}$ ) either in single or combined applications are capable of stimulating hydrocarbon degradation and restoring a crude oil polluted soil. There was loss in THC in both soils amended with cow dung as well as $\mathrm{H}_{2} \mathrm{O}_{2}$. The loss in THC of soil amended with hydrogen peroxide corroborate the work of DiIaconi et al., (2006) which shows that hydrogen peroxide concentration plays an important role in the reduction of TPH of oily sludge. Tsai and Kao (2009) also reveal that $15 \%$ and $30 \%$ aqueous solution of $\mathrm{H}_{2} \mathrm{O}_{2}$, which corresponded to the hydrogen peroxide concentrations of 150 and $300 \mathrm{mg} / \mathrm{L}$, respectively,as an oxygen source for crude oil polluted soil leads to $43 \%$ and $47 \%$ of TPH reduction from soil respectively after 40 hours of treatment, while $1 \%$ aqueous solutions of $\mathrm{H}_{2} \mathrm{O}_{2}$ reduces only $1.1 \% \mathrm{TPH}$. This shows that increasing $\mathrm{H}_{2} \mathrm{O}_{2}$ concentration will lead to a corresponding increase in hydrocarbon reduction.

A soil physiochemical characteristic is an indication of the health of a soil. A healthy soil is require to have normal $\mathrm{pH}$ range (close to neutrality), high nutrient (nitrate, potassium, phosphate, etc.) contents that are require for normal plant growth. Animal manures have been reported to improve the physiochemical conditions of the soil as well as providing conducive environment for microbial degradation (Ikpe and Powel, 2002). Cow dung provided the necessary nutrients such as nitrogen and phosphorus for microbial optimal performance in crude oil biodegradation. This may have been responsible for the loss of THC in the cow dung amended treatments.

The addition of organic manure to the crude oil polluted soil increase the soil $\mathrm{pH}$ as was evidenced in treatments $\mathrm{A}$ and $\mathrm{C}$. The unpolluted soil had the least $\mathrm{pH}$ increase at the end of the experiment. The results also confirm earlier findings of Ijah and Antai, (2003); Ijah et al., (2008), that organic manure have buffering effect on crude oil polluted soil. This is because crude oil pollution has been reported to decrease soil pH (Gighi et al., 2012). The range of the $\mathrm{pH}$ observed in the amended soils may favours oil degradation by micro-organisms as observed in similar studies that higher $\mathrm{pH}$ range between 6 and 9 provides better conditions for degradation of hydrocarbons since most microorganisms especially bacteria capable of degrading hydrocarbons perform best at $\mathrm{pH}$ conditions close to neutrality (Atlas and Bartha, 1992; Tanee and Kinako, 2008). The increase in soil $\mathrm{pH}$ due to addition of cow dung could have caused an increase in microbial activity during the process of decomposition and organic matter formation. This could have led to the release of more exchangeable bases that reduces $\mathrm{pH}$ of the soil towards neutrality. This assertion is true since there was increase in electrical conductivity in the amended soil. This is similar to the findings of Nel et al., (1999). Sedat and Sahriye (2011) also report that organic manure influences the soil electrical conductivity of crude oil polluted soils.

The decreased seen in the total organic matter (TOM) and total organic carbon (TOC) in the amended treatments could be as a result of carbon utilization by soil micro organisms as energy source for the oil degradation due to favourable $\mathrm{pH}$ level. This is in line with Lee et al., (1995) who reported that organic manures have effects in stimulating crude oil degradation by increasing the total heterotrophic microbial growth and activity. This assertion is true since there was increase in heterotrophic microbial population in this study.

There was decrease in the nitrate content of the amended soil while that of the un-amended soil increased. The decrease in nitrate content of the amended soil could be that it served as a source of nutrient for oil degraders. Onuh et al., (2008) had also observed a decrease in nitrogen availability with increased levels of crude oil pollution.Also, there was a decrease in the phosphate and potassium contents in all the treatments. It can be inferred that phosphorus and potassium were also utilized by soil micro organisms for oil degradation. 
Significant reduction in THC with improvement in both the physiochemical properties and nutritional status of the soil were found to be highest in treatment A (polluted soil amended with only cow dung), followed by $\mathrm{C}$ (polluted soil amended with combination of cow dung and $\mathrm{H}_{2} \mathrm{O}_{2}$ ). This observation is true since the hydrocarbon degrading micro-organisms were found to increase significantly in these treatment options. The favourable environmental conditions provided by the amendment materials lead to an increase in the microbial population and metabolism which invariably increase their ability to degrade hydrocarbon products.

Conclusion: The study revealed that the adverse effects of crude oil pollution on soils can be ameliorated by addition of organic manure (cow dung) and supplying oxygen to the soil by the use of hydrogen peroxide. These amendment materials (cow dung and hydrogen peroxide) enhanced the physiochemical characteristics of the soil thereby leading to a great reduction in the total hydrocarbon contents of the amended soils.The amendment treatments either single or combined application have the capacity to restore a crude oil polluted soil. It was also observed that combined application does not offer any advantage over the single treatment as the use of cow dung single application amendment option was the best in this study.

\section{REFERENCES}

Abii, T. A.; Nwosu, P. C. 2009.The effect of oilspillage on the soil of Eleme in Rivers State of the Niger Delta area of Nigeria, Research Journal of Environmental Sciences, 3(3): 316320 .

Agbogidi, O.M., Eruotor, P.G: Akparobi S.O; Nnaji, G.U. 2007. Evaluation of crude oil contaminated soil on the mineral elements of maize (Zea mays, L). J. Agron. 6(1): 188 -193.

Anyanwu, D.I; Awi-waadu G.D.B; Tanee F.B.G; Ochekwu EB. 2014. Fundamental Principles of Ecology. M \& J Grand Orbit Communications Ltd, Port Harcourt.

Atlas, R..M; Bartha, R. 1992. Hydrocarbon biodegradation and oil spill

bioremediation.Advances in Microbial Ecology, 12: 287- 338

Ayotamuno, J.M.,; Kogbara, R.B.; Taleat, M.O. 2006. Bioremediation of a petroleum- hydrocarbon polluted agricultural soil at different levels of water application in Port Harcourt, Nigeria. J. Food, Agric. Environ. 4 (3\&4): 214217.

Bidwell, J.R., Donald, S.C.;Merski, T. 2002. Toxicity evaluation of a commercial bioremediation agent mixed with crude oil. Environ. Toxicol.and Chemistry 22(1): 84-91.

Boopathy, R. 2001. Factors limiting bioremediation technologies. Bioresour. Technol. 74: 63-67.

Dilaconi, C. Ramadori, R.; Lopez, A. 2006 Combined biological and chemical degradation for treating a mature municipal landfill leachate.J. Biol.Eng, 31:118-124.

Gighi, J. G.; Tanee, F. B. G.; Albert, E. 2012.Postimpact Soil Assessments of Crude Oil Spill Site in Kpean Community in Khana LGA (Ogoni) of Rivers State, Nigeria.Journal of Science, 2(2): $109-120$.

IITA (International Institute of Tropical Agriculture), 1979.Selected methods for soil and plant analysis.Manual for soil and plant analysis.International Institute of Tropical Agriculture, pp: 6-7.

Ijah, U.J.J.; Antai, S.P. 2003.The potential use of chicken-drop microorganisms for oil spill remediation.The Environmentalist 23: 89-95.

Ijah, U.J.J., Safiyanu, H.; Abioye, O.P. 2008 Comparative study of Biodegradation of Crude oil in soil amended with Chicken droppings and NPK fertilizer. Sci. World J. 3(2): 63-67.

Ikpe, F.N.; Powel, J.M. 2002 Nutrient cycling practices and changes in soil properties in the crop - livestock farming systems of western Niger Republic of West Africa. Nutrient Cycling in Agroecosystem 62:37-45.

Lee, K., Tremblay G.H;Cobanli, SE. 1995. Bioremediation of oil beach sediments: Assessment of inorganic and organic fertilizers. Proceedings of 1995 oil spill conference of American Petroleum Institute, Washington DC. 101-119.

Michael, A.M; Ojha, T.P. 2006. Principles of Agricultural Engineering Vol. II. 5th, Edition, Jain Brothers, New Delhi, pp. 331 - 390. 
Nel, P.C; Bernard, R.O; Steynberg, R.E.; De Beer, J.M; Groeneveld, H.T. 1999. Trends in maize grain yields in long-term fertilizer trial. Elsevier Science B.V, FieldCrop Research 47(1): 53-64.

Okoh, A.I. 2006. Biodegradationalternative in the cleanup of petroleum hydrocarbon pollutants. $A$ review Biotechnology and Molecular Biology 1(2): $38-50$

Onuh, M.O; Madukwe, D.K.;Ohia, G.U. 2008. Effects of poultry manure and cow dung on the physical and chemical properties of crude oil polluted soil. Sci. World J. 3(2): 45 - 50.

Osuji, L.C.; Adesiyan, S.O., 2005. The Isiokpo oilpipeline leakage: Total organic carbon/organic matter contents of affected soils. Chem. Biodiversity. 2: 1079 - 1085.

Powel, J.M.; Ikpe, F.N.; Somala, Z.C.; Rivera, S.F. 1998. Urine effects on soil chemical properties and the impact of urine and dung on pearl millet yield. Experital Agric. 3:250-279.

Sedat, C.; Sahriye, S. 2011. Effects of chemical fertilizers and different organic manures application on soil $\mathrm{pH}, \mathrm{EC}$ and organic matter content.Journal of Food, Agriculture and Environment (JFAE), 9(3 \& 4): 739-741.
Stewarte, E.A., Grimshaw, H.M. Parkinson, J..A.; Quarmby, C 1974. Chemical Analysis of Ecological Materials.Blacwell Publications. London.

Tanee, F.B.G.; Kinako, P.D.S. 2008. Comparative Studies of Biostimulation and phytoremediation in the mitigation of crude oil toxicity in tropical soil.J. Appl. Sci. Environ. Manage. 12(2): 143 147.

Tsai, T.T; Kao, C.M. 2009. Treatment of petroleumhydrocarbon contaminated soils using hydrogen peroxide oxidation catalyzed by waste basic oxygen furnace slag. J Hazard Mater 170:466472

USEPA, 1971. Methods for the Chemical Analysis of Water and Wastes (MCAWW) (EPA/600/479/020).

Wyszkowski, M.; Ziolkowska, A. 2008. Effect of petrol and diesel oil on content of organic carbon and mineral components in soil.Am-Eur. J. Sust. Agric. 2(1): $54-60$. 